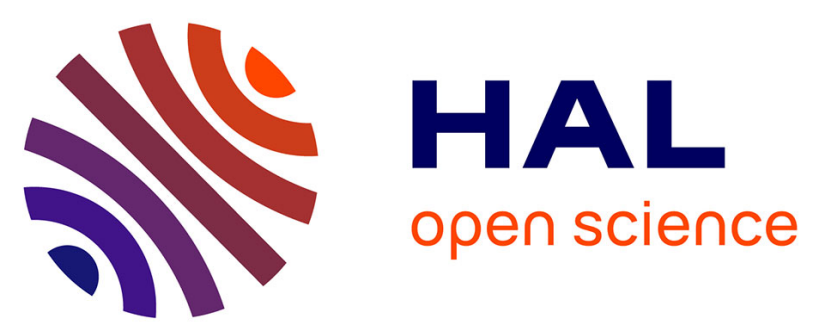

\title{
Toxicity of $\mathrm{CeO} 2$ nanoparticles on a freshwater experimental trophic chain: A study in environmentally relevant conditions through the use of mesocosms
}

Agathe Bour, Florence Mouchet, Stéphane Cadarsi, Jérôme Sylvestre, Laurent

Verneuil, David Baqué, Eric Chauvet, Jean-Marc Bonzom, Christophe Pagnout, Hugues Clivot, et al.

\section{To cite this version:}

Agathe Bour, Florence Mouchet, Stéphane Cadarsi, Jérôme Sylvestre, Laurent Verneuil, et al.. Toxicity of $\mathrm{CeO} 2$ nanoparticles on a freshwater experimental trophic chain: A study in environmentally relevant conditions through the use of mesocosms. Nanotoxicology, 2016, 10 (2), pp.245-255. 10.3109/17435390.2015.1053422 . hal-01494965

\section{HAL Id: hal-01494965 https://hal.science/hal-01494965}

Submitted on 24 Mar 2017

HAL is a multi-disciplinary open access archive for the deposit and dissemination of scientific research documents, whether they are published or not. The documents may come from teaching and research institutions in France or abroad, or from public or private research centers.
L'archive ouverte pluridisciplinaire HAL, est destinée au dépôt et à la diffusion de documents scientifiques de niveau recherche, publiés ou non, émanant des établissements d'enseignement et de recherche français ou étrangers, des laboratoires publics ou privés. 


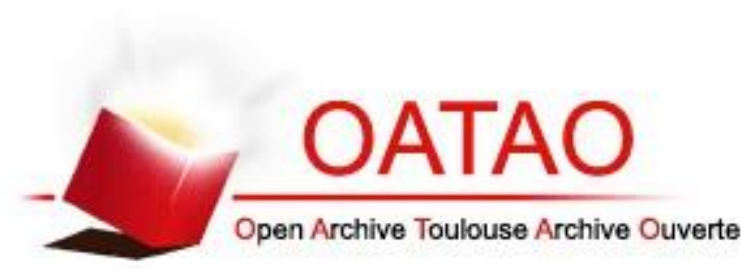

\section{Open Archive TOULOUSE Archive Ouverte (OATAO)}

OATAO is an open access repository that collects the work of Toulouse researchers and makes it freely available over the web where possible.

This is an author-deposited version published in : http://oatao.univ-toulouse.fr/ Eprints ID : 15745

To link to this article : DOI : $10.3109 / 17435390.2015 .1053422$

URL : http://dx.doi.org/10.3109/17435390.2015.1053422

To cite this version : Bour, Agathe and Mouchet, Florence and Cadarsi, Stéphane and Sylvestre, Jérôme and Verneuil, Laurent and Baqué, David and Chauvet, Eric and Bonzom, Jean-Marc and Pagnout, Christophe and Clivot, Hugues and Fourquaux, Isabelle and Tella, Marie and Auffan, Mélanieand Gauthier, Laury and Pinelli, Eric Toxicity of $\mathrm{CeO} 2$ nanoparticles on a freshwater experimental trophic chain: $\mathrm{A}$ study in environmentally relevant conditions through the use of mesocosms. (2016) Nanotoxicology, vol. 10 (n`2). pp. 245-255. ISSN 1743-5390

Any correspondence concerning this service should be sent to the repository administrator: staff-oatao@listes-diff.inp-toulouse.fr 


\title{
Toxicity of $\mathrm{CeO}_{2}$ nanoparticles on a freshwater experimental trophic chain: A study in environmentally relevant conditions through the use of mesocosms
}

\author{
Agathe Bour ${ }^{1,2}$, Florence Mouchet ${ }^{1,2}$, Stéphanie Cadarsi ${ }^{1,2}$, Jérôme Silvestre ${ }^{1,2}$, Laurent Verneuil ${ }^{1,2}$, David Baqué ${ }^{1}$, \\ Eric Chauvet ${ }^{3}$, Jean-Marc Bonzom ${ }^{2,4}$, Christophe Pagnout ${ }^{2,5}$, Hugues Clivot ${ }^{2,5}$, Isabelle Fourquaux ${ }^{6}$, Marie Tella ${ }^{2,7}$, \\ Mélanie Auffan ${ }^{2,7}$, Laury Gauthier ${ }^{1,2}$, and Eric Pinelli ${ }^{1,2}$ \\ ${ }^{1}$ CNRS, Université de Toulouse, INP, UPS, EcoLab (Laboratoire d'écologie fonctionnelle et environnement) UMR 5245, ENSAT, Avenue de \\ I'Agrobiopole, Castanet Tolosan, France, ${ }^{2}$ International Consortium for the Environmental Implications of Nanotechnology (iCEINT), \\ Aix-en-Provence, France, ${ }^{3}$ CNRS, Université de Toulouse, INP, UPS, EcoLab (Laboratoire d'écologie fonctionnelle et environnement) UMR 5245, \\ Toulouse, France, ${ }^{4}$ Laboratoire de Radioécologie et d'Ecotoxicologie, IRSN (Institut de Radioprotection et de Sûreté Nucléaire), DEI/SECRE, \\ Cadarache, France, ${ }^{5}$ CNRS, Université de Lorraine, LIEC (Laboratoire Interdisciplinaire des Environnements Continentaux) UMR 7360, Metz, France, \\ ${ }^{6}$ CMEAB (Centre de Microscopie Electronique Appliqué à la Biologie), Université Paul Sabatier, Faculté de Médecine Rangueil, Toulouse, France, and \\ ${ }^{7}$ CNRS, Université d'Aix-Marseille, CEREGE UMR 7330, Aix-en-Provence, France
}

\section{Abstract}

The toxicity of $\mathrm{CeO}_{2} \mathrm{NPs}$ on an experimental freshwater ecosystem was studied in mesocosm, with a focus being placed on the higher trophic level, i.e. the carnivorous amphibian species Pleurodeles waltl. The system comprised species at three trophic levels: (i) bacteria, fungi and diatoms, (ii) Chironomus riparius larvae as primary consumers and (iii) Pleurodeles larvae as secondary consumers. NP contamination consisted of repeated additions of $\mathrm{CeO}_{2} \mathrm{NPs}_{\text {over }} 4$ weeks, to obtain a final concentration of $1 \mathrm{mg} / \mathrm{L}$. NPs were found to settle and accumulate in the sediment. No effects were observed on litter decomposition or associated fungal biomass. Changes in bacterial communities were observed from the third week of NP contamination. Morphological changes in $\mathrm{CeO}_{2} \mathrm{NPs}$ were observed at the end of the experiment. No toxicity was recorded in chironomids, despite substantial NP accumulation $(265.8 \pm 14.1 \mathrm{mg} \mathrm{Ce} / \mathrm{kg})$. Mortality $(35.3 \pm 6.8 \%)$ and a mean Ce concentration of $13.5 \pm 3.9 \mathrm{mg} / \mathrm{kg}$ were reported for Pleurodeles. Parallel experiments were performed on Pleurodeles to determine toxicity pathways: no toxicity was observed by direct or dietary exposures, although Ce concentrations almost reached $100 \mathrm{mg} / \mathrm{kg}$. In view of these results, various toxicity mechanisms are proposed and discussed. The toxicity observed on Pleurodeles in mesocosm may be indirect, due to microorganism's interaction with $\mathrm{CeO}_{2} \mathrm{NPs}$, or NP dissolution could have occurred in mesocosm due to the structural complexity of the biological environment, resulting in toxicity to Pleurodeles. This study strongly supports the importance of ecotoxicological assessment of NPs under environmentally relevant conditions, using complex biological systems.
\end{abstract}

\section{Keywords}

Amphibian, chironomidae, ecotoxicity, litter decomposition, microorganisms

\section{Introduction}

Past decades have seen the emergence of new manufactured materials: nanoparticles (NPs). These particles in the size range of $1-100 \mathrm{~nm}$ present unique properties, making them highly attractive in many fields of application, including medical purposes (Huang et al., 2011), information and energy storage systems (Rao \& Cheetham, 2001) and many consumer products (The Royal Society, 2004). Among these particles, cerium dioxide NPs $\left(\mathrm{CeO}_{2}\right.$ NPs) are widely used as fuel catalysts and for anti-UV effects in coatings, paints and cosmetics (Quik et al., 2010). Produced in large amounts (100-1000 tons/year) in Europe (Piccinno et al.,

Correspondence: Florence Mouchet, EcoLab, Campus ENSAT, Avenue de l'Agrobiopôle, 31326 Castanet-Tolosan, France. Tel: +33 5343237 56. E-mail: florence.mouchet@ensat.fr
2012), $\mathrm{CeO}_{2}$ NPs belong to the OECD priority testing list of representative manufactured nanomaterials (OECD, 2010).

Therefore, several studies have investigated the toxicity of $\mathrm{CeO}_{2} \mathrm{NPs}$, and they were determined to be acutely toxic to daphnids (García et al., 2011; Lee et al., 2009), chironomids (Lee et al., 2009), nematodes (Roh et al., 2010; Zhang et al., 2011), algae (Manier et al., 2011, 2013; Rogers et al., 2010) and bacteria (Thill et al., 2006), from concentrations in the range of the $\mathrm{mg} / \mathrm{L}$. The induction of sub-lethal effects was also shown, with reproduction impairments being observed on nematodes (Roh et al., 2010) and daphnids (Manier et al., 2011), as well as growth inhibition and malformations observed on fish at $10 \mathrm{mg} / \mathrm{L}$ (Jemec et al., 2012) and genotoxic effects observed on amphibian species (Bour et al., 2015), chironomids and daphnids (Lee et al., 2009). These studies have been conducted according to standardized procedures, enabling a rapid evaluation of NP toxicity at broad 
ranges of concentrations. However, although necessary as a first step of NP ecotoxicity evaluation, standardized ecotoxicity assays are not representative of realistic environmental conditions of exposure. Studies concerning NP ecotoxicity in environmentally relevant conditions have been conducted very recently. Among these studies, mesocosm studies have been conducted to determine NP behavior and toxicity in complex environments (Buffet et al., 2013b; Cleveland et al., 2012; Colman et al., 2014; Ferry et al., 2009; Lowry et al., 2012; Schierz et al., 2014). These studies are still scarce, though indispensable: modest effects within a single trophic level can ramify and amplify through the ecological network and influence the function of the entire ecosystem (Jabiol et al., 2013). Moreover, physico-chemical transformation of NPs (e.g. colloidal destabilization, adsorption, dissolution) in complex environments can change the nature of the interactions with living organisms. NP toxicity can thus be different in complex ecosystems than in single exposure (Wiesner et al., 2009).

The amphibian species Pleurodeles waltl. is a well-known indicator of the genotoxic potential of contaminants (Djomo et al., 2000; Fernandez et al., 1993), referenced in the ISO standardized assay for the evaluation of genotoxicity by measurement of the induction of micronuclei (ISO 21427-1, 2006). This model organism also presents the advantage of being carnivorous, making it particularly interesting for food chain studies. The macro-invertebrate Chironomus riparius is representative of many freshwater ecosystems and has been widely used in ecotoxicology. Chironomid larvae have important activities of sediment reworking and biofilm grazing, making them potential vectors for trophic transfer. Nitzschia palea and Navicula pelliculosa are benthic diatoms living in numerous freshwater ecosystems. They represent a valuable source of food for many aquatic organisms and are at the base of multiple trophic webs. The toxicity of $\mathrm{CeO}_{2} \mathrm{NPs}$ on $P$. waltl., $C$. riparius and $N$. palea have previously been studied in standardized exposure conditions (Bour et al., 2015).

This study intends to go further in the comprehension of $\mathrm{CeO}_{2}$ NP toxicity in environmentally relevant exposure conditions, using larvae of the amphibian $P$. waltl. as top-consumers of an experimental trophic chain. For this purpose, we used indoor aquatic mesocosms to perform integrated assessment of $\mathrm{CeO}_{2} \mathrm{NP}$ impacts in complex environment. This study was complemented with parallel experiments where Pleurodeles larvae were exposed to $\mathrm{CeO}_{2}$ NPs by direct or dietary exposure. Mesocosms are complex systems comprising (i) a bacterial consortium and the diatom species $N$. palea and $N$. pelliculosa as primary producers, (ii) C. riparius larvae as primary consumers and (iii) Pleurodeles larvae, as predator species at the top of the trophic chain. The complete study of $\mathrm{CeO}_{2} \mathrm{NP}$ fate and effects in mesocosm has already been studied (Auffan et al., 2014) and is beyond the scope of this article. This study focuses on the impacts on Pleurodeles larvae, as the final endpoint of the trophic chain. Other species present in mesocosm are studied as vectors of contamination through the trophic chain.

\section{Materials and methods}

\section{Nanoparticles}

$\mathrm{CeO}_{2}$ NPs (Nanograin ${ }^{\circledR}$, Umicore, Olen, Belgium) were provided as a powder preparation and subsequently suspended in ultrapure water at $10 \mathrm{~g} / \mathrm{L}$. They are non-coated particles of cerine with a face centered cubic crystal structure. They have zeta potential of $+42 \pm 2 \mathrm{mV}$ and hydrodynamic diameters centered on $90 \pm 2 \mathrm{~nm}$ in stock suspension ( $\mathrm{pH}$ 3.1). Zeta potential and hydrodynamic diameters were measured using Malvern zetasizer and nanoZS (Malvern Instruments Ltd., Malvern, UK). Primary size and shape were determined in stock suspension and exposure media by
Transmission Electron Microscopy (TEM, JeolJsm 2100F, HR, JEOL USA, Inc., Peabody, MA) coupled to Energy Dispersive Xray spectroscopy (EDX, SDD Bruker, Billerica, MA). Size distribution is determined by image analysis (Image $J^{\circledR}$ Software, National Institutes of Health, Bethesda, MD) on a sample of 100 NPs.

\section{Organisms}

Diatoms ( $N$. palea and $N$. pelliculosa), chironomid (C. riparius) and amphibian $(P$. waltl.) larvae were grown at EcoLab Laboratory (Toulouse, France). Diatoms were cultured in CHU 10 medium with Fe-EDTA as an iron source (http://uwaterloo.ca/ canadian-phycological-culture-centre/cultures/culture-media/chu10). Pleurodeles larvae were obtained and grown as described in Mouchet et al. (2011). Chironomid larvae were obtained and grown following standardized procedures (AFNOR, 2004). A natural microbial consortium was recovered from water filters of the freshwater Museum-Aquarium of Nancy (France).

\section{Exposure methods}

\section{Mesocosm experiment}

Six mesocosms (glass tanks; $75 \times 20 \times 60 \mathrm{~cm}$; Figure 1) were filled with reconstituted sediment ( $89 \%$ silica sand, $10 \%$ kaolin, $1 \%$ calcium carbonate) and Volvic ${ }^{\circledR}$ water. Each mesocosm contained $6.5 \mathrm{~L}$ of reconstituted sediment and $56 \mathrm{~L}$ of water and was equipped with a water recirculating system connected to a pump (Eheim universal, $600 \mathrm{~L} / \mathrm{h}$ ). Natural light was provided by T8 tubes $\left(18 \mathrm{~W}, 5500 \mathrm{~K}\right.$, Vivalite $\left.{ }^{\circledR}\right)$ under 16:8 light-dark cycles and temperature was maintained at $21 \pm 1{ }^{\circ} \mathrm{C}$. Temperature, conductivity, $\mathrm{pH}$, redox potential and dissolved oxygen were monitored continuously (Ponsel Odeon open $\mathrm{X}$ probes kit). $\mathrm{NO}_{3}{ }^{-}$, $\mathrm{NO}_{2}{ }^{-}$and $\mathrm{NH}_{4}{ }^{+}$rates were controlled every 3 days with a colorimetric assay kit (Tetra, Germany). Dissolved organic carbon (DOC) was measured in the water column by infrared detection of $\mathrm{CO}_{2}$ produced by catalytic oxidation at $680^{\circ} \mathrm{C}$. Experimental conditions were realized in three replicates, with random assignation of mesocosms.

Experiment implementation. Senescent alder (Alnus glutinosa Gaertn.) leaves (3.2 g dry mass/mesocosm) and microorganisms (a microbial consortium and the diatoms $N$. palea and N. pelliculosa, $1.10^{6}, 2.10^{2}$ and $2.10^{4}$ cells $/ \mathrm{ml}$, respectively)

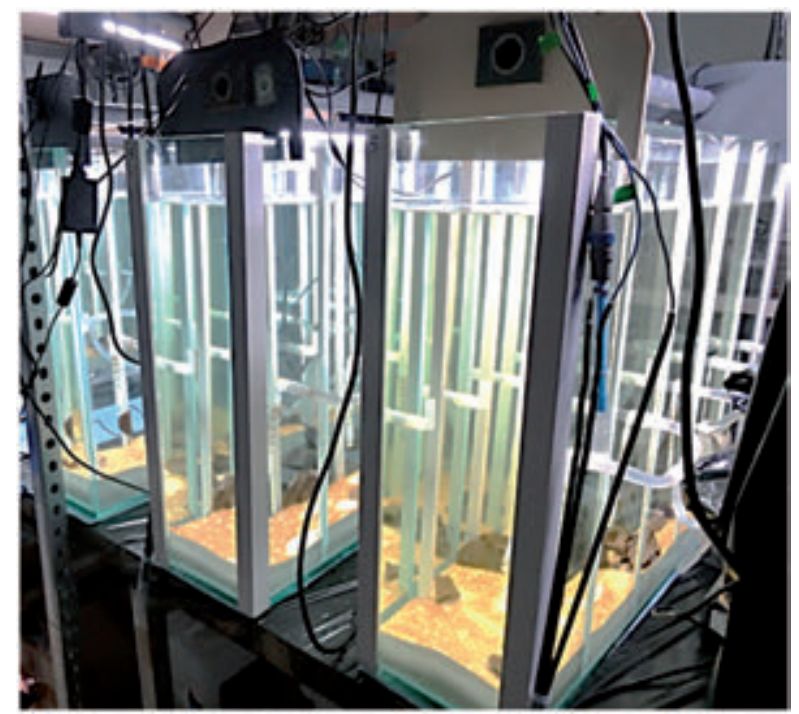

Figure 1. Aquatic mesocosms before NP contamination (T0). 
were added at the beginning of the experiment. Biofilm was allowed to develop for two weeks before NP contamination (Figures 2 and 3). Contamination consisted of repeated addition of NPs: 12 additions of fresh NP suspension $(50 \mathrm{ml}$ of $93.4 \mathrm{mg} / \mathrm{L}$ per input) were realized over 4 weeks. Deionized water was added in control mesocosms instead of NP suspension. After 1 week of contamination (T1), 700 chironomid larvae aged of $72 \mathrm{~h}$ were added to each mesocosm. Seventeen Pleurodeles larvae at stage 53 of development (Gallien \& Durocher, 1957) were introduced 1 week later (T2). The experiment ended 12 days later (T4): amphibian larvae were withdrawn from mesocosms for immediate toxicity assessment and sediment was sieved to collect remaining chironomids then stored in $70 \%$ ethanol for further analysis. The overall implementation is presented in Figure 3.

\section{Direct exposure}

Direct exposure of Pleurodeles larvae was performed according to standardized test for mincronucleus induction assessment (ISO 21427-1, 2006). Groups of 15 larvae at stage 53 of development
(Gallien \& Durocher, 1957) were exposed in Volvic ${ }^{\circledR}$ water for 12 days, with daily medium renewal. $\mathrm{CeO}_{2} \mathrm{NP}$ concentrations ranged from 0.015 to $1.4 \mathrm{mg} / \mathrm{L}$. A standard mutagen (monohydrate cyclophosphamide $2 \mathrm{mg} / \mathrm{L}$; ISO 21427-1, 2006; Sigma, France) was used as a positive control. At the end of the exposure, larvae were allowed to depurate for two days in non-contaminated Volvic $^{\circledR}$ water.

\section{Dietary exposure}

As a first step, chironomid larvae (7 days old) were exposed to $\mathrm{CeO}_{2} \mathrm{NPs}$ at $1 \mathrm{mg} / \mathrm{L}$ for $48 \mathrm{~h}$. Exposure was performed in Volvic ${ }^{\circledR}$ water (without sediments). Larvae from control group (control chironomids) were placed in non-contaminated Volvic ${ }^{\circledR}$ water.

Pleurodeles dietary exposure is adapted from standardized procedures (ISO 21427-1, 2006). Larvae $(n=20)$ at stage 53 of development (Gallien \& Durocher, 1957) are individually placed in $200 \mathrm{~mL}$ of Volvic ${ }^{\circledR}$ water for 12 days, with water renewal every 2 days. Every day, the same number of chironomids previously exposed was provided to each Pleurodeles larvae. The control
Figure 2. Experimental trophic chain studied in mesocosm. (A) Schematic representation of trophic relations between species, from consumers to prey. (B) Primary compartment before NP contamination. Biofilm cannot develop under alder leaves due to a lack of light, leaving white patches when leaves move. (C) Chironomus riparius larvae grazing biofilm. (D) Pleurodeles waltl. larvae hunting chironomid larvae.
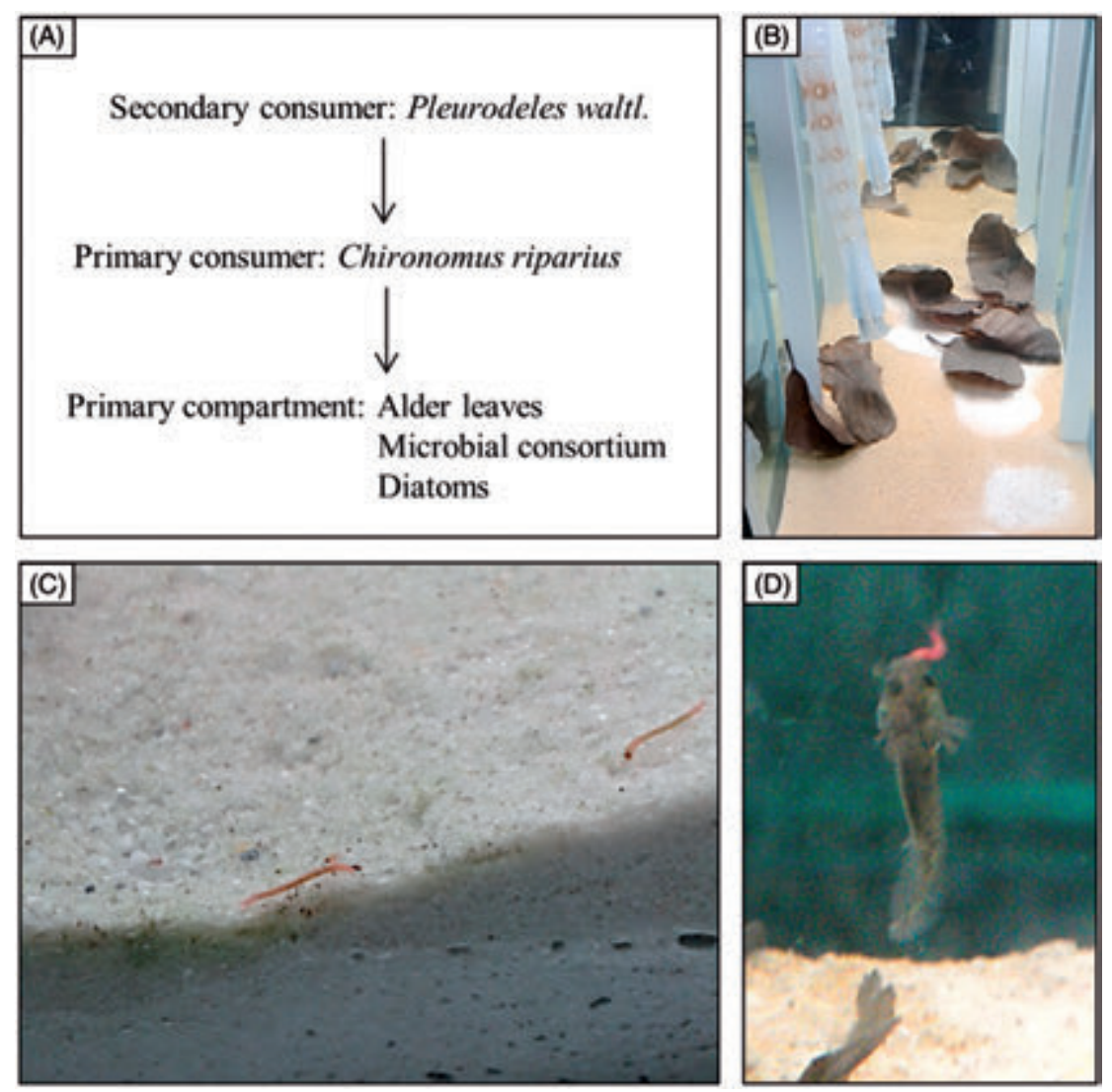

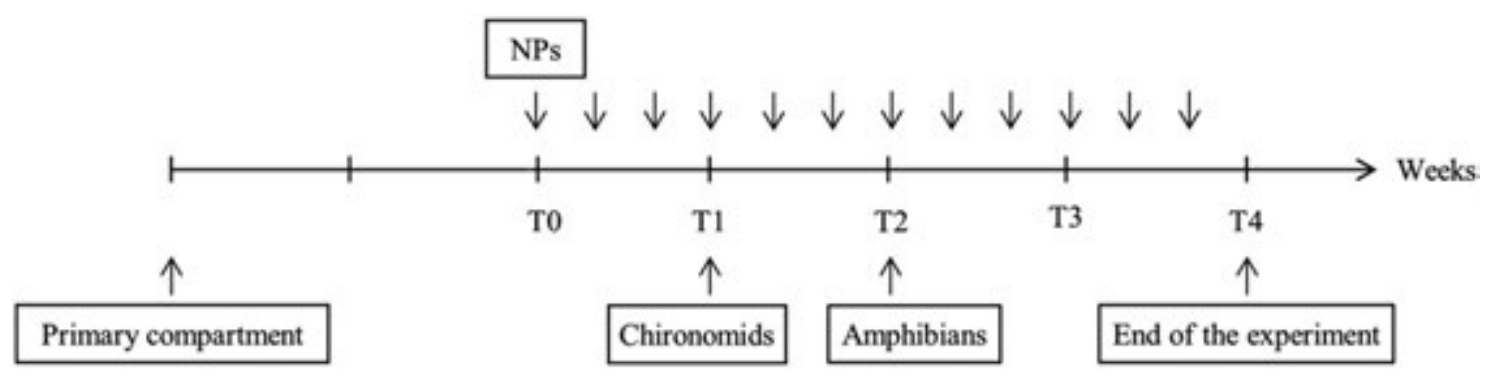

Figure 3. Schematic representation of mesocosm experiment implementation. 
group $(n=10)$ was fed on control chironomids, and the contaminated group $(n=10)$ was fed on contaminated chironomids. The number of chironomids was increased over time to comply with the growing needs of the Pleurodeles. Before feeding the Pleurodeles larvae, the chironomids were gently rinsed with deionized water but not allowed to depurate, to mimic natural conditions where depuration does not occur. Pleurodeles were allowed to depurate for two days and gently rinsed with deionized water at the end of the exposure, for bioaccumulation assessment purposes.

Pleurodeles exposure water was sampled before renewal to assess Ce release from organisms.

\section{NP quantification}

Ce concentrations were measured in water, in sediment and in organisms by ICP-MS (PerkinElmer, NexIon 300X, Shelton, CT). In mesocosms, water was sampled at $10 \mathrm{~cm}$ below the surface before the first NP addition (T0), before chironomid and Pleurodeles larvae introduction (T1 and $\mathrm{T} 2$, respectively) and at the end of the experiment (T4), and analyzed for total and dissolved Ce. The dissolved fraction was estimated after ultracentrifugation $(80000 \mathrm{rpm}, 1 \mathrm{~h})$. Surficial sediment $(10 \mathrm{~mm})$ was sampled at the end of the experiment for total Ce concentrations after acidic digestion. In addition, cores were analyzed to get $\mathrm{Ce}$ contents in $1 \mathrm{~mm}$-deep slices. Ce concentrations in organisms were measured in triplicates (pools of three Pleurodeles and 20 chironomid larvae). Water, sediment and organisms samples were prepared as described in Tella et al. (2014).

\section{Toxicity assessment}

\section{Toxicity on Pleurodeles larvae}

Toxicity assessment on Pleurodeles was consistent for the three exposure methods. Acute toxicity was expressed as percentage and determined as the total number of dead larvae, counted and removed daily. Genotoxicity was assessed as micronuclei induction in erythrocytes from circulating blood, as described in Mouchet et al. (2011) and in accordance with the standardized ISO procedure (ISO 21427-1, 2006).

Nanoparticle internalization was assessed on gills and intestine for the mesocosm experiment and on intestine only for dietary exposure experiment. After blood sampling, larvae were dissected and organs were fixed in $2 \%$ glutaraldehyde in sodium phosphate buffer, post-fixed in $1 \%$ osmium tetroxide, dehydrated and embedded in Embed812-Araldite502 resin. Ultra-thin sections (50-90 nm deep) were mounted on copper grids and subsequently stained in lead citrate and uranyl acetate solutions. Observations were performed on high resolution TEM-EDX (JeolJsm 2100F, HR - SDD Brucker).

\section{Litter decomposition and effects on associated organisms}

Leaf litter decomposition. The proportion of leaf mass remaining at T4 was measured by dividing the final ash-free dry mass (AFDM) of leaves by their initial AFDM. Both final and initial $(n=5)$ organic matter contents were determined on $500 \mathrm{mg}$ portions of ground samples ashed at $550{ }^{\circ} \mathrm{C}$ for $4 \mathrm{~h}$.

Fungal biomass was estimated on five frozen-dried leaf disks (12 mm diameter) per leaf sample, using ergosterol contents (Gessner \& Chauvet, 1993). Ergosterol was extracted and partially purified by solid-phase extraction, then separated and quantified using HPLC. Treatment effects on remaining leaf AFDM and leaf-associated fungal biomass (expressed as ergosterol per leaf AFDM) were assessed using an analysis of variance (ANOVA) test (SigmaPlot, Version 12.0 Software, Systat Software Inc., San Jose, CA).
Effects on bacterial communities. Toxicity on bacterial communities was assessed by denaturing gradient gel electrophoresis (DGGE) analysis as described in Clivot et al. (2012). Pelagic microorganisms were sampled every week by water filtration (total volume of $100 \mathrm{ml}$, filtered at $0.45 \mu \mathrm{m}$ ). Detailed information on DNA extraction and DGGE analysis procedures are provided in Supplementary Material.

Toxicity on chironomid larvae. Larval growth was determined at $\mathrm{T} 4$ by measuring body length (Image ${ }^{\circledR}$ software). Organism sizes were compared with a Kruskal-Wallis test followed by Dunn's test to analyze differences between groups (SigmaPlot, Version 12.0 Software).

\section{Results}

\section{Mesocosm experiment}

\section{Physico-chemical parameters of the water column}

Variation curves are presented in Supplemental Figure S1 (Supplementary Material). $\mathrm{pH}$ values were comprised between 8.0 and 8.7 with a slight increase at the beginning of the experiment. A peak in oxygen rate was also observed at this period and then values decreased and stabilized at approximately $90-120 \%$ of saturation. In contrast, redox potential slightly decreased at the beginning of the experiment and quickly stabilized at approximately $320 \mathrm{mV}$. Finally, conductivity slightly increased over time, with values ranging from 200 to $230 \mu \mathrm{S} / \mathrm{cm}$. No significant variations were observed between conditions, except for $\mathrm{pH}$ with the first input of NPs: a slight decrease (from 8.5 to 7.7) was observed in the contaminated condition. However, a quick recovery was observed and no significant differences with control were recorded until the end of the experiment. At T0 (first NP introduction) and until the end of the exposure, $\mathrm{NO}_{3}{ }^{-}, \mathrm{NO}_{2}{ }^{-}$and $\mathrm{NH}_{4}{ }^{+}$concentrations were at the lowest detectable values $(0,<0.3$ and $0 \mathrm{mg} / \mathrm{L}$, respectively). No significant differences in DOC contents in water were observed between conditions $(p<0.05)$, with mean values of $2.9 \pm 0.3$ and $3.4 \pm 0.2 \mathrm{mg} / \mathrm{L}$ for control and contaminated condition, respectively.

\section{Ce concentrations in water and sediment}

Ce concentration in the water column increased over time to reach $35 \pm 8 \mu \mathrm{g} / \mathrm{L}$ (3.5\% of total Ce introduced) at T4 (Figure 4A). The fraction of dissolved Ce represented $2.6 \%$ of total Ce in water at this time. Mean Ce concentration in the first $\mathrm{cm}$ of sediment was $5.5 \pm 2.2 \mathrm{mg} / \mathrm{kg}$, with most of the $\mathrm{Ce}(60 \%)$ found in the first $\mathrm{mm}$ (Figure 4B).

\section{Leaf litter and microorganisms}

Bacterial community structure distances indicated differences among communities in control and NP conditions, from the third week of contamination (Figure 5). ANOSIM performed on the DGGE profiles confirmed that bacterial communities from NP condition were different from those of control condition, with more pronounced effects being observed at the end of the experiment. No significant differences between conditions $(p>0.05)$ were observed in both the percentage of leaf AFDM remaining $(12.0 \pm 0.1$ and $11.9 \pm 0.2 \%$ for control and NP conditions, respectively; Supplemental Figure S2) and leafassociated fungal biomass $(28.7 \pm 8.0$ and $44.2 \pm 12.8 \mathrm{mg} / \mathrm{g}$ for control and NP conditions, respectively; Supplemental Figure S3) at the end of the experiment. 
Figure 4. Ce concentrations (A) in the water column, at different sampling times and (B) in the sediment at T4. Data are corrected from background concentrations determined in control mesocosm.
(A)

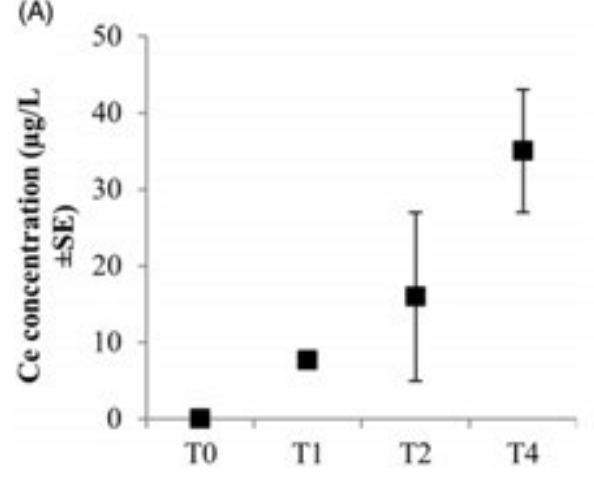

(B) Ce concentration $(\mathrm{mg} / \mathrm{kg})$

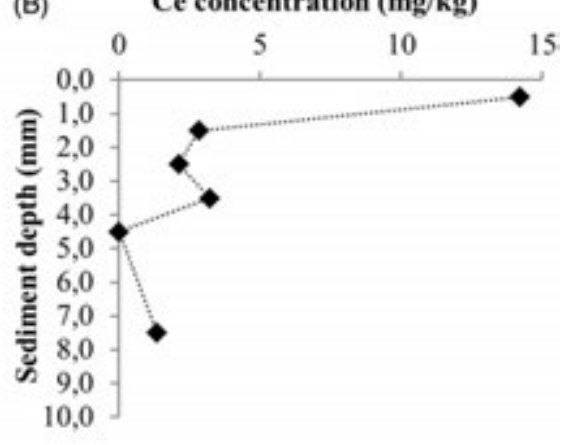

Figure 5. NMDS plots of DGGE pelagic bacterial community profiles from control (white squares) and NP (grey squares) conditions, before the first NP addition (T0) and after 1, 2, 3 and 4 weeks (T1, T2, T3 and T4, respectively) of contamination.
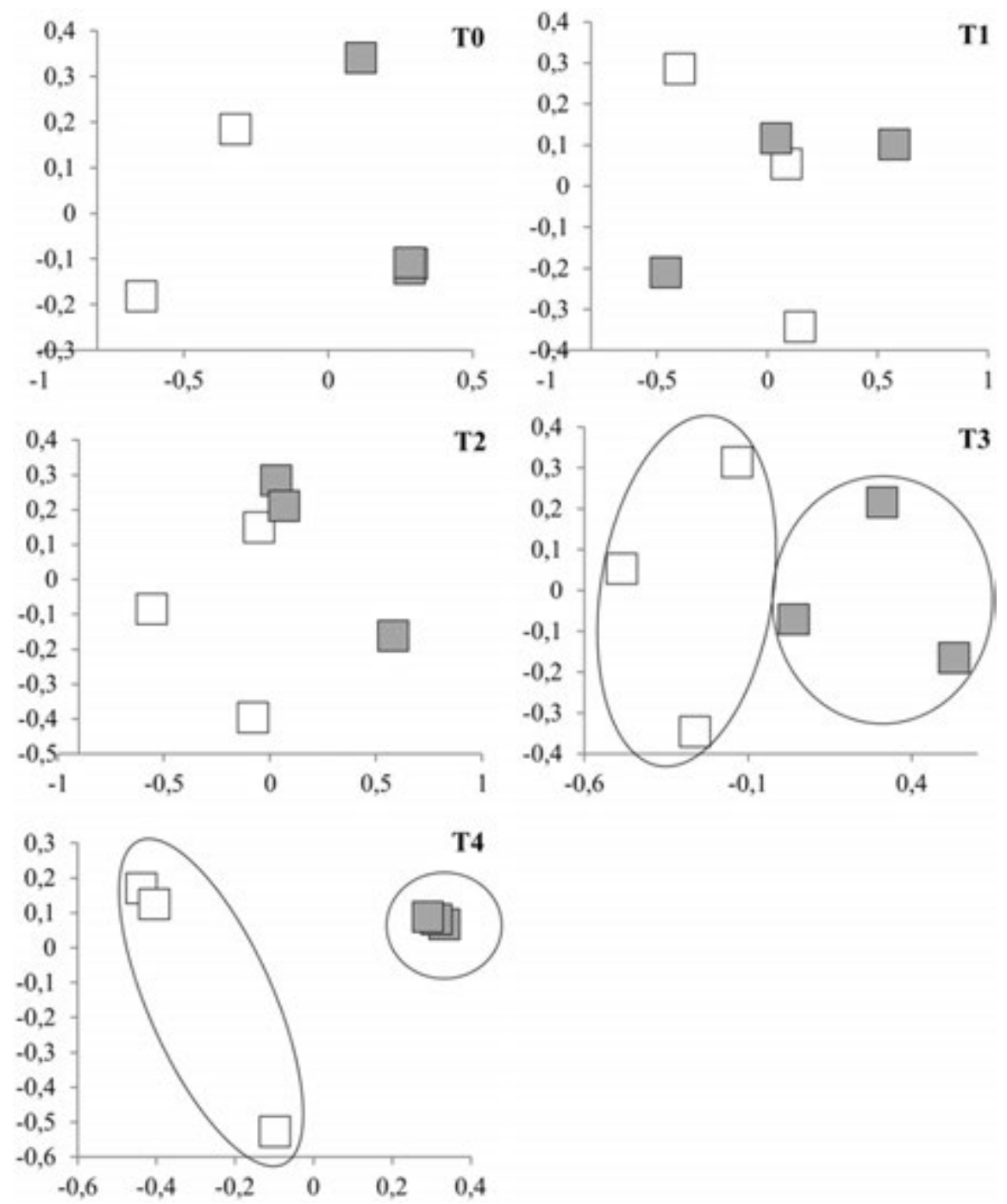

\section{Chironomids}

Less than 50 larvae remained at the end of the experiment in both conditions, with no significant difference between conditions. Growth assessment on remaining larvae showed no difference between conditions, with mean sizes of $11.4 \pm 0.2$ and $11.5 \pm 0.2 \mathrm{~mm}$ for control and NP conditions, respectively (Supplemental Figure S4). Ce quantification indicated substantial NP accumulation in chironomid larvae, with $265.8 \pm 14.1 \mathrm{mg} / \mathrm{kg}$ of dry body weight. No Ce was detected in control groups.

\section{Pleurodeles}

Significant mortality $(35.3 \pm 6.8 \%)$ was observed in NP condition, whereas no mortality occurred in control groups. Moreover, visual observation indicated that contrary to control conditions, surviving larvae in NP condition exhibited a strong disturbance of general health (no hunting behavior or response to mechanical stimulation). Therefore, genotoxicity was not assessed for this experiment because of the high level of intoxication of Pleurodeles larvae. TEM investigation performed on gills and 
intestine did not allow NP internalization to be observed; no NPs were observed inside the gills or across the intestinal epithelium. However, Ce quantification in Pleurodeles larvae indicated significant NP accumulation, with a Ce mean concentration of $13.5 \pm 3.9 \mathrm{mg} / \mathrm{kg}$ of dry body weight (Figure 6 and Table 1). No Ce was detected in control groups.

\section{Nanoparticles}

Water was sampled at the end of the exposure $(10 \mathrm{~cm}$ below the water surface) and analyzed by TEM-EDX to determine NP size. While NPs in stock suspension are large $(8-61 \mathrm{~nm}$, median size of $25 \mathrm{~nm}$; see Figure 7 for size distribution) with multiple edges (Figure 8A), NPs at the end of mesocosm exposure were significantly smaller $(<4 \mathrm{~nm}$, Figures 7 and $8 \mathrm{E}-\mathrm{G})$.

\section{Direct exposure in standardized conditions}

No toxicity was observed in Pleurodeles larvae exposed to $\mathrm{CeO}_{2}$ NPs via the water column. No mortality was recorded and no significant genotoxicity was observed at any of the concentrations tested (Figure 9). NP accumulation in larvae was observed for

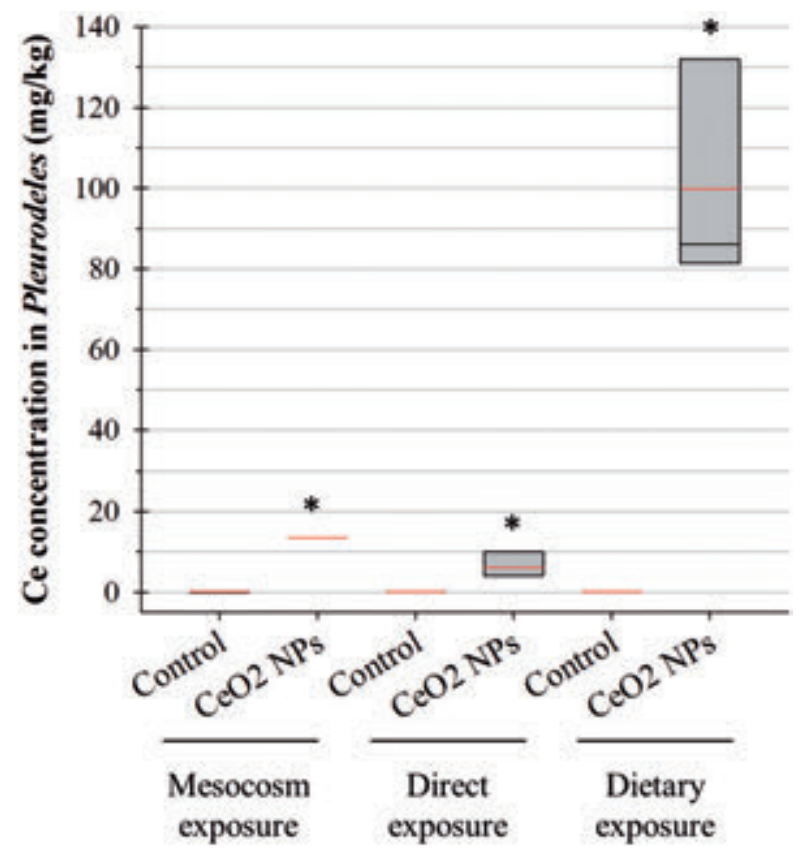

Figure 6. Value distribution of Ce concentrations in $P$. waltl. larvae, for different methods of exposure at similar concentrations. For direct exposure, selected data correspond to the initial concentration of $1.4 \mathrm{mg} /$ L. Box plots show the medians, 10, 25, 75 and 90th percentiles. Red lines show mean values. *Significantly different from control. every concentration tested with Ce concentrations ranging from 1.21 to $6.11 \mathrm{mg} / \mathrm{kg}$ of dry body weight (Figure 6 and Supplemental Figure S5).

\section{Dietary exposure}

Important NP accumulation was observed in chironomid larvae, with a mean Ce concentration of $445 \pm 137 \mathrm{mg} / \mathrm{kg}$ of dry body weight. Visual observation showed that chironomid larvae were ingested quickly $(<30 \mathrm{~min})$, and $\mathrm{Ce}$ was not detected in the Pleurodeles water exposure before renewal.

An important NP accumulation was observed in Pleurodeles larvae, with a mean Ce concentration of $99.9 \pm 16.1 \mathrm{mg} / \mathrm{kg}$ of dry body weight (Figure 6 and Table 1). Despite this significant NP accumulation, neither mortality nor genotoxicity were observed for Pleurodeles.

TEM observation of larvae intestine showed no evidence of NP absorption through intestinal epithelium: as for mesocosm exposure, no NP was observed to cross the epithelium.

\section{Discussion}

To date, few studies on NPs have been performed in complex exposure systems. Among them, studies on species at different trophic levels are scarce (Auffan et al., 2014; Ferry et al., 2009; Kulacki et al., 2012; Zhang et al., 2012a). This study investigates the toxicity of $\mathrm{CeO}_{2}$ NPs in mesocosms, on species representative of three different trophic levels: litter and microbial communities as primary producers/consumers, chironomid larvae as primary consumers and the predator Pleurodeles larvae as secondary consumers. Severe toxicity was observed on Pleurodeles, leading to investigations of different parameters possibly involved in NP toxicity mechanisms.

\section{Indirect effects due to system functioning}

The experimental trophic chain studied (Figure 2) has been designed to be self-sufficient over the entire experiment. However, impacts on primary producers or consumers could alter this balance. First, biofilm observation indicated that it was well-developed in both conditions until amphibian introduction. Moreover, chironomid larvae had almost reached their maximum size $(12-14 \mathrm{~mm})$ at the end of the experiment, even in the presence of NPs, indicating enough food supply for these organisms. Changes observed in bacterial communities could have induced disturbances in the nitrogen cycle and the production of highly toxic compounds, such as $\mathrm{NO}_{2}{ }^{-}$, but measurement of nitrogen compounds in mesocosms did not reveal any changes.

Moreover, our results showed that $\mathrm{CeO}_{2}$ NPs did not alter the activity of leaf decomposers, i.e. microorganisms and chironomid larvae, and the rate of leaf decomposition.

Table 1. Toxicity and NP accumulation in $P$. waltl. larvae observed for different exposure methods.

\begin{tabular}{lccc}
\hline & $\begin{array}{c}\text { Mesocosm } \\
\text { exposure }\end{array}$ & Direct exposure & $\begin{array}{c}\text { Dietary } \\
\text { exposure }\end{array}$ \\
\hline Toxicity on Pleurodeles & $\begin{array}{c}35.3 \pm 6.8 \% \\
\text { mortality }^{\mathrm{a}} \\
\text { Genotoxicity: } n d^{\mathrm{b}} \\
13.5 \pm 3.9\end{array}$ & $\begin{array}{c}\text { No mortality } \\
\text { No genotoxicity }\end{array}$ & $\begin{array}{c}\text { No mortality } \\
\text { No genotoxicity }\end{array}$ \\
$\begin{array}{c}\text { Ce concentration in } \\
\text { Pleurodeles }(\mathrm{mg} / \mathrm{kg})^{\mathrm{a}}\end{array}$ & $6.1 \pm 2.0$ & $99.9 \pm 16.1$ \\
\hline
\end{tabular}

${ }^{\mathrm{a}}$ Mean values \pm standard error.

${ }^{\mathrm{b}}$ Not determined. 
Leaf litter decomposition results in the formation and release of fine particulate organic matter that can interact with NPs and stabilize them (Manier et al., 2011; Quik et al., 2010). It could be hypothesized that organic compounds potentially toxic are also released in the water column due to litter decomposition, even though the amount of leaf litter was relatively low. An increase in litter decomposition could have thus led to potentially harmful effects. However, the absence of significant differences in litter decomposition between conditions, in accordance with the similar DOC content in water, indicates that the observed toxicity on Pleurodeles is not directly related to the detrital food web.

Finally, chironomid larvae were not impacted by NPs. Very few chironomid larvae remained at the end of the experiment $(<50$ over 700$)$ and no emergence was observed (i.e. chironomids stayed under larval form and did not leave the water column). Previous studies on C. riparius (Bour et al., 2015) showed that the $\mathrm{CeO}_{2}$ NPs did not induce mortality on this species at a broad range of concentrations $(0.01-100 \mathrm{mg} / \mathrm{L})$. This indicates that the high number of missing larvae is most likely due to predation by the amphibians rather than mortality due to NPs. The study of larval growth also showed that chironomids almost reached their maximum size $(12-14 \mathrm{~mm})$. Altogether, these results indicate that the toxicity observed on Pleurodeles is not likely to be due to a lack of food, compared to control conditions.

\section{Implication of different routes of exposure}

In mesocosms, Pleurodeles are likely to be exposed to NPs via two pathways: direct exposure from water column and dietary exposure via contaminated chironomids. Parallel experiments conducted on Pleurodeles allow better understanding of the implications for these two routes of exposure in the toxicity observed in mesocosms.

\section{Direct exposure}

The absence of toxicity observed in this experiment indicates that direct exposure to $\mathrm{CeO}_{2}$ NPs is not likely to be a major source of toxicity to Pleurodeles, at least in these exposure conditions. Indeed, as standardized and mesocosm exposure conditions are completely different, results cannot be directly extrapolated from an experiment to the other and are rather indicative of a general mechanism of action of $\mathrm{CeO}_{2} \mathrm{NPs}$.

\section{Dietary exposure}

The rapid ingestion of chironomid larvae suggests that they are not likely to depurate, the contact time with non-contaminated water being very short. This is confirmed by the Ce concentrations in the water below the detection limits, besides indicating that $\mathrm{Ce}$ is not released in the water by Pleurodeles either. These results confirm that Pleurodeles exposure occurred only via trophic route during this experiment. Moreover, the important NP concentration measured in the larvae after depuration indicates that $\mathrm{CeO}_{2}$ NPs are accumulated when ingested. The absence of toxicity on Pleurodeles larvae during this experiment indicates that trophic route does not play a major role in the toxicity of $\mathrm{CeO}_{2}$ NPs on this species, despite the observed accumulation.

These experiments and the associated absence of toxicity on Pleurodeles indicate that the toxicity observed in mesocosm cannot be entirely explained by direct exposure or dietary exposure to $\mathrm{CeO}_{2} \mathrm{NPs}$, considered independently.

\section{Role of NP accumulation}

The three exposure methods presently studied at comparable concentrations ( $1 \mathrm{mg} / \mathrm{L}$ for mesocosm and dietary exposure; $1.4 \mathrm{mg} / \mathrm{L}$ for direct exposure) induced variable NP accumulation in Pleurodeles, with dietary exposure resulting in the most significant accumulation. However, accumulation values should not be compared between experiments as Pleurodeles exposure to NPs varied importantly. Indeed, the average number of chironomid larvae available per Pleurodeles was different between dietary and mesocosm exposure (96 and 38, respectively) and NP accumulation in chironomid larvae also varied between conditions (445 and $265.8 \mathrm{mg} / \mathrm{kg}$ for dietary and mesocosm exposure, respectively).

However, comparing the effects observed during the different exposure highlights that toxicity is not correlated with $\mathrm{CeO}_{2} \mathrm{NP}$ accumulation, as shown in Table 1. Indeed, no toxicity occurred with the extremely high NP concentration of $\sim 100 \mathrm{mg} / \mathrm{kg}$ of dry body weight in Pleurodeles, but mortality was observed at the intermediate accumulation value $(13.5 \mathrm{mg} / \mathrm{kg})$, in mesocosm experiment. This result is in accordance with previous studies that underline that no direct relationship exists between NP bioaccumulation and toxicity (Buffet et al., 2013a; Jackson et al., 2012).

\section{Nano-bio and bio-nano interactions}

Nanoparticles interact with their environment and can be modified on contact with complex matrices (Wiesner et al., 2011). Lowry et al. (2012) report chemical modifications of Ag NPs in long-term mesocosm exposure. Similarly, biotransformation of $\mathrm{CeO}_{2}$ NPs was observed in contact with plant systems
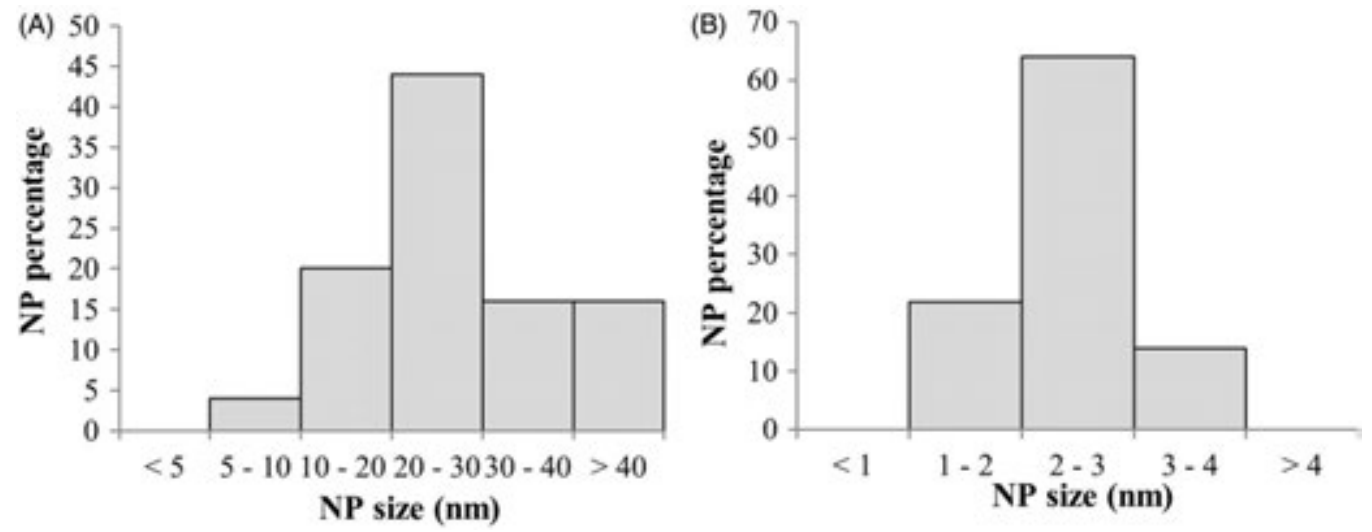

Figure 7. NP size distributions (A) in stock suspension at T0 and (B) in mesocosm water column at T4. NP size is determined from TEM pictures (Image ${ }^{\circledR}$ software), on a total sample of $100 \mathrm{NP}$ per condition. 
Figure 8. Transmission electron microscopy (TEM) coupled to Energy Dispersive X-ray microscopy (EDX) analysis of $\mathrm{CeO}_{2} \mathrm{NPs}(\mathrm{A})$ in stock suspension, (B) in direct exposure medium, after $24 \mathrm{~h}$ of exposure (before renewal), (C, D) in chiromid larvae intestine after $48 \mathrm{~h}$ of exposure (dietary exposure) and $(\mathrm{E}, \mathrm{G})$ in mesocosm exposure medium, at the end of the experiment. (G) EDX analysis of sample from mesocosm exposure, performed in the zone indicated by a white circle in $\mathrm{E}$. $\mathrm{Cu}$ spike corresponds to the copper grid.
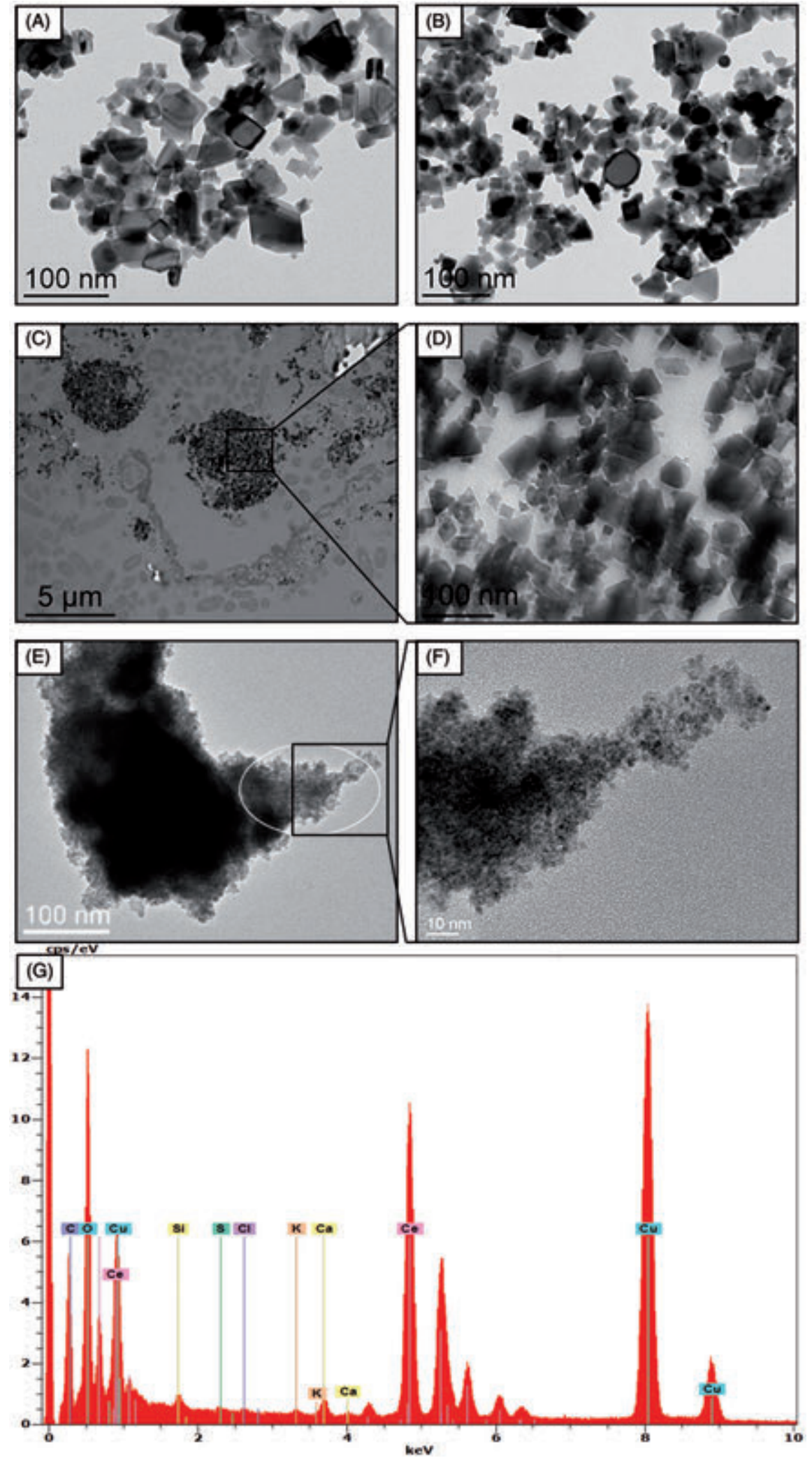

(Zhang et al., 2012b). In this study, $\mathrm{CeO}_{2} \mathrm{NPs}$ were found to undergo morphological changes in mesocosm exposure, with important size decrease (Figure 7) and erosion of NP edges, indicating mass loss. The most abundant elements detected by EDX analyses on MET observations were $\mathrm{Ce}$ and $\mathrm{O}$, while $\mathrm{P}$ was not detected (Figure 8G). These results support the presence of $\mathrm{CeO}_{2}$ NPs instead of $\mathrm{CePO}_{4}$ mineral phases. It has been reported that NPs with rough surfaces, corners and edges can be biologically and chemically highly reactive (George et al., 2012; Pelletier et al., 2010). In the present mesocosm experiment, chemical reactions may have occurred at the numerous contact points from NP edges, resulting in edges erosion, size decrease and the release of ionic forms of $\mathrm{Ce}(2.6 \%$ of total $\mathrm{Ce}$ in the column water at the end of the experiment). This could explain 


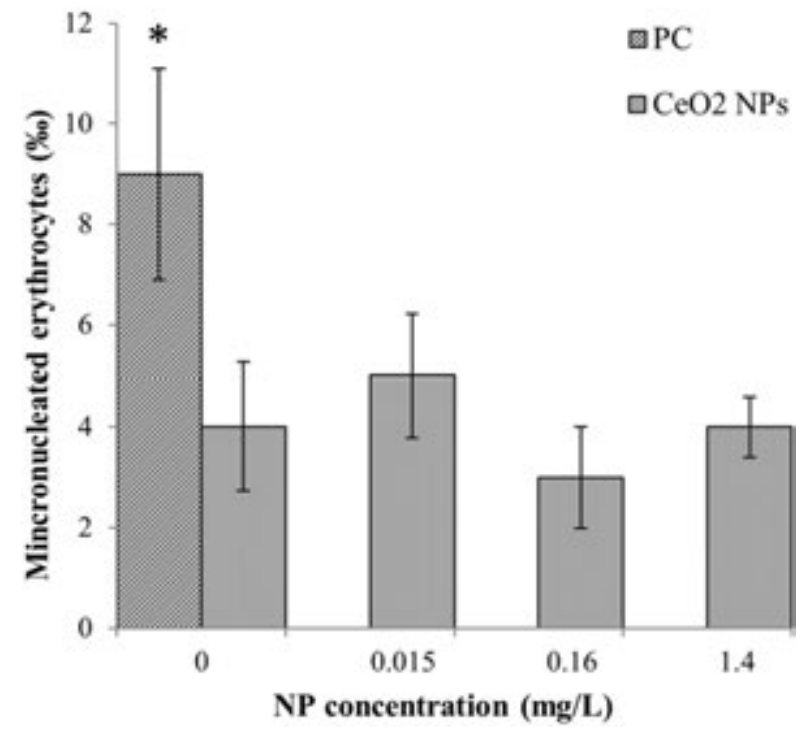

Figure 9. Genotoxicity on $P$. waltl. larvae directly exposed to $\mathrm{CeO}_{2} \mathrm{NPs}$. Error bars show the $95 \%$ confidence interval of median values. PC: positive control. *Significantly different from control.

that the $\mathrm{CeO}_{2}$ NPs studied, initially large (up to $60 \mathrm{~nm}$ ) and nonspherical, were found to be significantly smaller $(<5 \mathrm{~nm})$ and spherical at the end of the experiment.

As shown in Figure 8, NP morphological changes were not observed in exposure medium of standardized exposure or in chironomid larvae gut during dietary exposure. The presence of microbial communities in mesocosms may have an important role in NP modifications. Indeed, several studies reported interactions between $\mathrm{CeO}_{2}$ NPs and microbial species (Fang et al., 2010; Manier et al., 2013; Thill et al., 2006; Zeyons et al., 2009). Other NP modifications can also occur in complex matrices due to the presence of many biological molecules (Nel et al., 2009) and these "nano-bio" interactions can have different impacts in terms of toxicity.

First, NP interaction with microbial species could result in indirect toxicity for other species due to toxin production. Indeed, fungi produce many secondary metabolites, especially as a defense against predators (Arsuffi \& Suberkropp, 1989). Similarly, Thill et al. (2006) suggested that the presence of molecules excreted by the bacteria prevented the direct contact between $\mathrm{CeO}_{2}$ NPs and the biological membranes, reducing the cytotoxicity. In this experiment, the observed changes in bacterial communities could have led to the predominance of bacterial species potentially harmful for Pleurodeles. Bacterial communities could also have reacted to $\mathrm{CeO}_{2} \mathrm{NPs}$ and released toxic organic molecules in the water. Similarly, even though fungal biomasses did not differ between conditions, it cannot be excluded that they produced mycotoxins in reaction to NPs. It thus can be hypothesized that such molecules could be the cause of the acute toxicity observed on Pleurodeles larvae in mesocosm.

A second hypothesis to explain the toxicity observed in mesocosm relates to NP speciation and dissolution. Unlike $\mathrm{ZnO}$ or $\mathrm{Ag} \mathrm{NPs}, \mathrm{CeO}_{2} \mathrm{NP}$ dissolution is generally considered negligible (Manier et al., 2013; Rogers et al., 2010). However, Zhang et al. (2012b) observed $\mathrm{CeO}_{2}$ NP biotransformation in plant systems, attributed to biogenic reducing substances and organic acids. They suggest that NPs are partially dissolved by organic substances and that the resulting $\mathrm{Ce}^{3+}$ ions are precipitated on root surfaces or form $\mathrm{CePO}_{4}$ or Ce-carboxyl compounds complexes. Furthermore, Thill et al. (2006) observed $\mathrm{CeO}_{2} \mathrm{NP}$ reduction in the presence of bacteria. Bioturbation may also impact the distribution and speciation of metallic contaminants (Lagauzère et al., 2009). In this study, it thus could be hypothesized that the presence of microbial communities or chironomids in mesocosm induces $\mathrm{CeO}_{2} \mathrm{NP}$ reduction, leading to $\mathrm{Ce}^{3+}$ release in the water column. Despite the rather low dissolved fraction of Ce measured in the water column, the observation of NP morphological changes and mass loss in mesocosm strongly supports the hypothesis of NP dissolution. Zeyons et al. (2009) suggest that soluble $\mathrm{Ce}^{3+}$ ions present in NP suspension could partly be the cause of the toxicity observed on the cyanobacteria Synechocystis PCC6803 exposed to $\mathrm{CeO}_{2}$ NPs. Therefore, although the initial $\mathrm{CeO}_{2} \mathrm{NP}$ form is not toxic, as suggested by the absence of toxicity in other experimental conditions, ionic or complexed forms potentially present in mesocosms could be toxic to Pleurodeles.

\section{Conclusions}

Mesocosm exposure to $\mathrm{CeO}_{2}$ NPs led to different responses depending on the organisms. No effects were observed on litter decomposition or on the associated fungal biomass, but changes in bacterial communities were observed from the third week of NP contamination. No effects were reported on chironomid larvae, despite a significant NP accumulation. The most severe toxicity was observed on Pleurodeles larvae, with a significant mortality in the presence of NPs. This toxicity on Pleurodeles was not observed in other exposure conditions: No toxicity was recorded on larvae directly exposed to NPs or via the trophic route. Moreover, no correlation between NP bioaccumulation and toxicity was observed. This suggests that complex phenomena occur in mesocosms and modulate NP toxicity. Different mechanisms are suggested: (i) $\mathrm{CeO}_{2}$ NPs in mesocosms could lead to indirect effects on Pleurodeles through microorganism reaction to $\mathrm{CeO}_{2}$ NPs and (ii) NP dissolution could have occurred in mesocosms, following changes in Ce speciation, leading to toxic compounds.

This study allowed validation of the feasibility of the simple carnivorous trophic chain "chironomid larvae - Pleurodeles larvae", with $\mathrm{CeO}_{2} \mathrm{NP}$ transfer from prey to predator. This study also enabled validation of the whole functioning of the complex system studied in mesocosms. Indeed, this system comprising species at different trophic levels has proven to be self-sufficient over a long exposure time, with $\mathrm{CeO}_{2} \mathrm{NP}$ transfer along the whole trophic chain. This complex system allowed detecting effects that could not be observed with standardized assays. Studies at intermediate size scales, as with these small size indoor mesocosms, are therefore crucial in the field of nano-ecotoxicology as they enable investigations on toxicity mechanisms in complex systems, while controlling certain biotic and abiotic parameters.

\section{Acknowledgements}

Thanks to Umicore company for providing $\mathrm{CeO}_{2} \mathrm{NPs}$. The authors also thank Sophie Caissaignon and Corinne Chaneac (Collège de France, Paris, France) for $\mathrm{CeO}_{2} \mathrm{NP}$ characterization and Sylvain Lamothe for his helpful technical assistance. The authors also thank the CNRS for funding the GDRi iCEINT. The English language of the manuscript has been corrected by an English language editing company.

\section{Declaration of interest}

This study was conducted in the frame of the ANR-10-NANO-0006/ MESONNET project, funded by the French National Research Agency (ANR). The authors report no conflict of interest. The authors alone are responsible for the content and writing of the paper. 


\section{References}

AFNOR. 2004. XP T 90-339-1. Détermination de la Toxicité des Sédiments vis-à-vis de Chironomus riparius. France: AFNOR.

Arsuffi TL, Suberkropp K. 1989. Selective feeding by shredders on leafcolonizing stream fungi: comparison of macroinvertebrate taxa. Oecologia 79:30-7.

Auffan M, Tella M, Santaella C, Brousset L, Paillès C, Barakat M, et al. 2014. An adaptable mesocosm platform for performing integrated assessments of nanomaterial risk in complex environmental systems. Sci Rep 4:5608. doi: 10.1038/srep05608.

Bour A, Mouchet F, Verneuil L, Evariste L, Silvestre J, Pinelli E, Gauthier L. 2015. Toxicity of $\mathrm{CeO}_{2}$ nanoparticles at different trophic levels - effects on diatoms, chironomids and amphibians. Chemosphere 120:230-6.

Buffet P-E, Pan J-F, Poirier L, Amiard-Triquet C, Amiard J-C, Gaudin P, et al. 2013a. Biochemical and behavioural responses of the endobenthic bivalve Scrobicularia plana to silver nanoparticles in seawater and microalgal food. Ecotoxicol Environ Saf 89:117-24.

Buffet P-E, Richard M, Caupos F, Vergnoux A, Perrein-Ettajani H, LunaAcosta A, et al. 2013b. A mesocosm study of fate and effects of $\mathrm{CuO}$ nanoparticles on endobenthic species (Scrobicularia plana, Hediste diversicolor). Environ Sci Technol 47:1620-8.

Cleveland D, Long SE, Pennington PL, Cooper E, Fulton MH, Scott GI, et al. 2012. Pilot estuarine mesocosm study on the environmental fate of Silver nanomaterials leached from consumer products. Sci Total Environ 421-422:267-72.

Clivot H, Pagnout C, Aran D, Devin S, Bauda P, Poupin P, Guérold F. 2012. Changes in soil bacterial communities following liming of acidified forests. Appl Soil Ecol 59:116-23.

Colman BP, Espinasse BP, Richardson CJ, Matson CW, Lowry G, Hunt D, et al. 2014. Emerging contaminant or an old toxin in disguise? Silver nanoparticle impacts on ecosystems. Environ Sci Technol 48: 5229-36.

Djomo JE, Ferrier V, Békaert C. 2000. Amphibian micronucleus test in vivo (Jaylet test) to evaluate the genotoxicity of petrochemical waste waters. Bull Environ Contam Toxicol 65:168-74.

Fang X, Yu R, Li B, Somasundaran P, Chandran K. 2010. Stresses exerted by $\mathrm{ZnO}, \mathrm{CeO}_{2}$ and anatase $\mathrm{TiO}_{2}$ nanoparticles on the Nitrosomonas europaea. J Colloid Interface Sci 348:329-34.

Fernandez M, L'Haridon J, Gauthier L, Zoll-Moreux C. 1993. Amphibian micronucleus test(s): a simple and reliable method for evaluating in vivo genotoxic effects of freshwater pollutants and radiations. Initial assessment. Mutat Res Mutagen Relat Subj 292:83-99.

Ferry JL, Craig P, Hexel C, Sisco P, Frey R, Pennington PL, et al. 2009. Transfer of gold nanoparticles from the water column to the estuarine food web. Nat Nanotechnol 4:441-4.

Gallien L, Durocher M. 1957. Table chronologique du développement chez Pleurodeles waltiii Michah. Bull Biol Fr Belg 91:97-114.

García A, Espinosa R, Delgado L, Casals E, González E, Puntes V, et al 2011. Acute toxicity of cerium oxide, titanium oxide and iron oxide nanoparticles using standardized tests. Desalination 269: 136-41.

George S, Lin S, Ji Z, Thomas CR, Li L, Mecklenburg M, et al. 2012. Surface defects on plate-shaped silver nanoparticles contribute to its hazard potential in a fish gill cell line and zebrafish embryos. ACS Nano 6:3745-59.

Gessner MO, Chauvet E. 1993. Ergosterol-to-biomass conversion factors for aquatic hyphomycetes. Appl Environ Microbiol 59: $502-7$.

Huang H-C, Barua S, Sharma G, Dey SK, Rege K. 2011. Inorganic nanoparticles for cancer imaging and therapy. J Control Release 155: 344-57.

ISO 21427-1. 2006. Evaluation of Genotoxicity by Measurement of the Induction of Micronuclei. Part 1: Evaluation of Genotoxicity using Amphibian Larvae. Geneva: ISO.

Jabiol J, McKie BG, Bruder A, Bernadet C, Gessner MO, Chauvet E. 2013. Trophic complexity enhances ecosystem functioning in an aquatic detritus-based model system. J Anim Ecol 82:1042-51.

Jackson BP, Bugge D, Ranville JF, Chen CY. 2012. Bioavailability, toxicity, and bioaccumulation of quantum dot nanoparticles to the amphipod Leptocheirus plumulosus. Environ Sci Technol 46: 5550-6.

Jemec A, Djinović P, Tišler T, Pintar A. 2012. Effects of four $\mathrm{CeO}_{2}$ nanocrystalline catalysts on early-life stages of zebrafish Danio rerio and crustacean Daphnia magna. J Hazard Mater 219-220: 213-20.

Kulacki KJ, Cardinale BJ, Keller AA, Bier R, Dickson H. 2012. How do stream organisms respond to, and influence, the concentration of titanium dioxide nanoparticles? A mesocosm study with algae and herbivores. Environ Toxicol Chem SETAC 31: 2414-22.

Lagauzère S, Boyer P, Stora G, Bonzom J-M. 2009. Effects of uraniumcontaminated sediments on the bioturbation activity of Chironomus riparius larvae (Insecta, Diptera) and Tubifex tubifex worms (Annelida, Tubificidae). Chemosphere 76:324-34.

Lee S-W, Kim S-M, Choi J. 2009. Genotoxicity and ecotoxicity assays using the freshwater crustacean Daphnia magna and the larva of the aquatic midge Chironomus riparius to screen the ecological risks of nanoparticle exposure. Environ Toxicol Pharmacol 28:86-91.

Lowry GV, Espinasse BP, Badireddy AR, Richardson CJ, Reinsch BC, Bryant LD, et al. 2012. Long-term transformation and fate of manufactured Ag nanoparticles in a simulated large scale freshwater emergent wetland. Environ Sci Technol 46:7027-36.

Manier N, Bado-Nilles A, Delalain P, Aguerre-Chariol O, Pandard P 2013. Ecotoxicity of non-aged and aged $\mathrm{CeO}_{2}$ nanomaterials towards freshwater microalgae. Environ Pollut 180:63-70.

Manier N, Garaud M, Delalain P, Aguerre-Chariol O, Pandard P. 2011. Behaviour of ceria nanoparticles in standardized test media influence on the results of ecotoxicological tests. J Phys Conf Ser 304:012058.

Mouchet F, Landois P, Datsyuk V, Puech P, Pinelli E, Flahaut E, Gauthier L. 2011. International amphibian micronucleus standardized procedure (ISO 21427-1) for in vivo evaluation of double-walled carbon nanotubes toxicity and genotoxicity in water. Environ Toxicol 26: $136-45$.

Nel AE, Mädler L, Velegol D, Xia T, Hoek EMV, Somasundaran P, et al. 2009. Understanding biophysicochemical interactions at the nano-bio interface. Nat Mater 8:543-57.

OECD. 2010. List of Manufactured Nanomaterials and List of Endpoints for Phase One of the Sponsorship Programme for the Testing of Manufactured Nanomaterials: Revision. Series on the Safety of Manufactured Nanomaterials No. 27. Paris: Organisation for Economic Co-operation and Development.

Pelletier DA, Suresh AK, Holton GA, McKeown CK, Wang W, Gu B, et al. 2010. Effects of engineered cerium oxide nanoparticles on bacterial growth and viability. Appl Environ Microbiol 76: 7981-9.

Piccinno F, Gottschalk F, Seeger S, Nowack B. 2012. Industrial production quantities and uses of ten engineered nanomaterials in Europe and the world. J Nanoparticle Res 14:1-11.

Quik JTK, Lynch I, Van Hoecke K, Miermans CJH, De Schamphelaere KAC, Janssen CR, et al. 2010. Effect of natural organic matter on cerium dioxide nanoparticles settling in model fresh water. Chemosphere 81:711-15.

Rao CNR, Cheetham AK. 2001. Science and technology of nanomaterials: current status and future prospects. J Mater Chem 11: 2887-94.

Rogers NJ, Franklin NM, Apte SC, Batley GE, Angel BM, Lead JR, Baalousha M. 2010. Physico-chemical behaviour and algal toxicity of nanoparticulate $\mathrm{CeO}_{2}$ in freshwater. Environ Chem 7:50.

Roh J-Y, Park Y-K, Park K, Choi J. 2010. Ecotoxicological investigation of $\mathrm{CeO}_{2}$ and $\mathrm{TiO}_{2}$ nanoparticles on the soil nematode Caenorhabditis elegans using gene expression, growth, fertility, and survival as endpoints. Environ Toxicol Pharmacol 29:167-72.

Schierz A, Espinasse B, Wiesner MR, Bisesi JH, Sabo-Attwood T, Ferguson PL. 2014. Fate of single walled carbon nanotubes in wetland ecosystems. Environ Sci Nano 1:574-83.

Tella M, Auffan M, Brousset L, Issartel J, Kieffer I, Pailles C, et al. 2014. Transfer, transformation, and impacts of ceria nanomaterials in aquatic mesocosms simulating a pond ecosystem. Environ Sci Technol 48: 9004-13.

The Royal Society. 2004. Nanoscience and Nanotechnologies: Opportunities and Uncertainties. London: The Royal Society.

Thill A, Zeyons O, Spalla O, Chauvat F, Rose J, Auffan M, Flank AM. 2006. Cytotoxicity of $\mathrm{CeO}_{2}$ nanoparticles for Escherichia coli. Physico-chemical insight of the cytotoxicity mechanism. Environ Sci Technol 40:6151-6. 
Wiesner MR, Lowry GV, Casman E, Bertsch PM, Matson CW, Di Giulio RT, et al. 2011. Meditations on the ubiquity and mutability of nanosized materials in the environment. ACS Nano 5:8466-70.

Wiesner MR, Lowry GV, Jones KL, Hochella J, Michael F, Di Giulio RT, et al. 2009. Decreasing uncertainties in assessing environmental exposure, risk, and ecological implications of nanomaterials. Environ Sci Technol 43:6458-62.

Zeyons O, Thill A, Chauvat F, Menguy N, Cassier-Chauvat C, Oréar C, et al. 2009. Direct and indirect $\mathrm{CeO}_{2}$ nanoparticles toxicity for Escherichia coli and Synechocystis. Nanotoxicology 3:284-95.
Zhang $\mathrm{H}$, He X, Zhang Z, Zhang $\mathrm{P}$, Li Y, Ma Y, Kuang $\mathrm{Y}$, et al. 2011. Nano- $\mathrm{CeO}_{2}$ exhibits adverse effects at environmental relevant concentrations. Environ Sci Technol 45: 3725-30.

Zhang P, He X, Ma Y, Lu K, Zhao Y, Zhang Z. 2012a. Distribution and bioavailability of ceria nanoparticles in an aquatic ecosystem model. Chemosphere 89:530-5.

Zhang P, Ma Y, Zhang Z, He X, Zhang J, Guo Z, et al. 2012b. Biotransformation of ceria nanoparticles in cucumber plants. ACS Nano 6:9943-50.

Supplementary material available online

Supplementary Figures S1-S5 